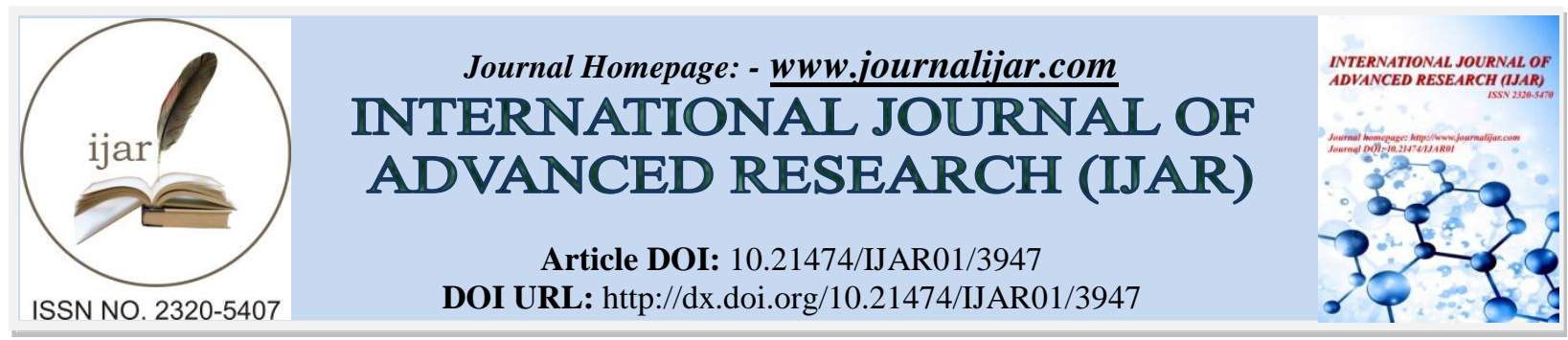

RESEARCH ARTICLE

\title{
SELF-ESTEEM OF ADOLESCENTS IN SCHOOL.
}

\section{S. Sumathy ${ }^{1}$ and Dr. G. Mettilda Bhuvaneswari ${ }^{2}$.}

1. Ph. D Research Scholar, Assistant Professor \& Head, Department of Social Work, Thanthai Hans Roever College (Autonomous), Perambalur, Tamil Nadu, India.

2. Assistant Professor, Department of Social Work, Cauveri College for Women, Trichy, Tamil Nadu, India.

\section{Manuscript Info}

Manuscript History

Received: 18 February 2017

Final Accepted: 19 March 2017

Published: April 2017

Key words:-

Adolescents, School, Self-esteem.

\begin{abstract}
Self-esteem plays a crucial role during the adolescence stage when adolescents start to observe changes. Adolescents' self-esteem is often affected by the physical and hormonal changes they experience during puberty. They are extremely concerned about how they look, they are perceived and accepted by their peers. High self-esteem is directly related to having a very supportive family and body image is a major component in adolescents' self-esteem. Adolescent's overall evaluation of his or her own worth as a self, such as how people feel about their physical appearance, skills, academic performance, and so on is reflected in their self-esteem. The aim of the present study was to assess the level of self-esteem of adolescents studying in Higher Secondary School. The researcher adopted descriptive research and using Dr. S. Karunanidhi's Self Esteem Questionnaire assessed the level of self-esteem of adolescents in school. Census method was adopted and data was collected from 300 adolescents. The findings of this study reveal that more than half of the respondents have low overall level of self- esteem.
\end{abstract}

Copy Right, IJAR, 2017,. All rights reserved.

\section{Introduction:-}

During puberty, the changes in the reproductive organs and external genitalia, also development of a new level of social awareness and moral judgement affect the adolescents. They form their own identities depending on how they cope with these adaptations. Their self-esteem develops by the ways they cope with these problems.

Self-esteem is how we feel about our self as a person. Adolescence is a time of confusion as they choose whether to become independent or dependent. In the early stages of development, children depend on their family for feedback, but in the adolescence stage most of them find it embarrassing to speak to family, about puberty and their feelings. It is common for them to listen to friends, and relate with them as they are on the same level. Therefore, adolescents' absorb the feedback of friends, which have an effect on their self-esteem. It is a common belief that positive view of the self makes a person to feel good about oneself, effectively cope with challenges and believe that people respect them. Self-esteem is important for psychological health and the present study examines the self-esteem among adolescents especially in higher secondary school.

Corresponding Author:- S. Sumathy.

Address:- Ph. D Research Scholar, Assistant Professor \& Head, Department of Social Work, Thanthai Hans Roever College (Autonomous), Perambalur, Tamil Nadu, India. 


\section{Review of Literature:-}

Harter $(1990,1999)^{[3]}$ in his studies show that levels of self-esteem appear different in gender. Girls seem to have lower levels of self-esteem than boys. "Research has found that satisfaction with physical appearance is a large component of self-esteem, and adolescence girls have greater dissatisfaction with physical appearance than boys".

Monique Bolognini, Bernard Plancherel, Walter Bettschart, Olivier Halfon (1996) ${ }^{[5]}$ in their longitudinal study of a general population ( $\mathrm{n}=219$; Mage: 12, 13 and 14) between 1990 and 1993 over 3 years in Lausanne (Switzerland) found that girls tend to have a poorer self-esteem than boys, whatever the domains taken into consideration. Differences are more significant with reference to appearance and athletic performance. As far as the development of self-esteem is concerned, there is no major change, notably when considering global perception. Global selfesteem has more influence on the level of depressive mood in girls than in boys.

The article of Kearney-Cooke A, (1999) Gender differences and self-esteem, gave information that the transition between childhood and adulthood-is usually accompanied by difficult changes in the life of a young person. An adolescent's personal development and self-esteem are influenced by biological, cognitive, social and environmental factors. Studies have shown that adolescent girls tend to have lower self-esteem and more negative assessments of their intellectual abilities and physical features than boys have. These findings explain the higher incidence of suicide attempts, depression, and eating disorders in girls.

Lauren G. Wild, Alan J. Flisher, Arvin Bhana, Carl Lombard (2004) ${ }^{[4]}$ investigated associations among adolescents' self-esteem in 6 domains (peers, school, family, sports/athletics, body image and global self-worth) and risk behaviours related to substance use, bullying, suicidality and sexuality. A multistage stratified sampling survey was used to select a representative sample of 939 English, Afrikaans and Xhosa-speaking students in Grades 8 and 11 at public high schools in Cape Town, South Africa. Participants completed the multidimensional Self-Esteem Questionnaire (SEQ; DuBois, Felner, Brand, Philips, \& Lease, 1996) and a self-report questionnaire containing items about demographic characteristics and participation in a range of risk behaviours. Scores on each self-esteem scale were significantly associated with atleast one risk behaviour in male and female adolescents after controlling for the sampling strategy, grade and race. However, specific self-esteem domains were differentially related to particular risk behaviours in adolescents of both sexes. Low body-image, self-esteem and global self-worth were also uniquely associated with risk behaviours in girls, but not in boys. The findings suggest that interventions that aim to protect adolescents from engaging in risk behaviours by increasing their self-esteem are likely to be most effective and cost-efficient if they are aimed at the family and school domains.

Daniel Clay, Vivian L. Vignoles, Helga Dittmar (2005) ${ }^{[2]}$ in their study of 136 U.K. girls aged $11-16$, found experimental exposure to either ultra-thin or average-size magazine models lowered body satisfaction and consequently, self-esteem. The study revealed that self-esteem was also lower among older than among younger girls. The results supported early educational interventions to help girls to deconstruct advertising and media images.

Akdemir D., Cak T., Aslan C., Aydos B.S., Nalbant K., Cuhadaroglu-Cetin F., (2016) ${ }^{[1]}$ in their study examined self-esteem and associated socio-demographical and psychological factors in clinically referred adolescents in Turkey. Three hundred forty-nine adolescents aged between 12 and 18 years admitted to the Department of Child and Adolescent Psychiatry with a psychiatric complaint were enrolled. Self-Esteem was lower in girls, adolescents without siblings, living in non-nuclear families, with a past suicide attempt, and with history of a non-suicidal selfinjurious behaviour. Self-esteem was negatively correlated with identity confusion on SIAF and positively correlated with acceptance/involvement on PSS. Significant predictors of self-esteem were gender, presence of a sibling, history of a NSSI and SIAF scores. Interactions between self-esteem and gender, psychiatric symptoms, parenting and identity development are complex in clinically referred adolescents.

\section{Methods and Materials:-}

Descriptive research design was adopted by the researcher. The universe of the study was 300 adolescents studying in the XI and XII standards of Government Higher Secondary School, Kurumbalur at Perambalur district of Tamil $\mathrm{Nadu}$. The researcher used census method and collected data from all the respondents. A self-prepared questionnaire was administered to understand the socio demographic details and Self Esteem Questionnaire of Dr. S. Karunanidhi, 
(1996) Professor \& Head, Department of Psychology, University of Madras, to assess the level of self- esteem in various dimensions.

\section{Objectives:-}

$>$ To understand the socio demographic details of the adolescents in school

$>$ To assess the level of self-esteem of adolescents

$>$ To suggest suitable measures to enhance self-esteem of adolescents

\section{Research Hypotheses:-}

1. There is a significant difference among the age of the adolescents with regard to their overall level of selfesteem

2. There is a significant difference between the gender of the adolescents and their overall level of self-esteem

3. There is a significant relationship between the community of the adolescents and their overall level of selfesteem

4. There is a significant difference between the education of the adolescents and their overall level of self-esteem

5. There is a significant association between the educational group of the adolescents and their overall level of self-esteem

6. There is a significant difference between the family type of the adolescents with regard to their overall level of self-esteem

7. There is significant association between the domicile of the adolescents and their overall level of self-esteem

8. There is a significant difference among the fathers' education of the adolescents with regard to their overall level of self-esteem

9. There is a significant difference between the occupational status of the adolescents' mothers and their overall level of self-esteem.

10. There is a significant difference among the family monthly income of the adolescents with regard to their overall level of self-esteem

Results and Discussion:-

Table 1:- Distribution of Respondents by the Socio-Demographic variables.

\begin{tabular}{|c|c|c|c|}
\hline \multicolumn{2}{|c|}{ Socio-Demographic Variables } & \multirow{2}{*}{$\begin{array}{c}\text { Frequency } \\
(\mathrm{n}=300) \\
54\end{array}$} & \multirow{2}{*}{$\begin{array}{c}\text { Percentage } \\
18.0\end{array}$} \\
\hline Age (in years) & 15 & & \\
\hline & 16 & 137 & 45.6 \\
\hline & 17 & 101 & 33.7 \\
\hline & 18 & 8 & 2.7 \\
\hline \multirow[t]{2}{*}{ Gender } & Male & 145 & 48.3 \\
\hline & Female & 155 & 51.7 \\
\hline \multirow[t]{3}{*}{ Religion } & Hindu & 284 & 94.7 \\
\hline & Christian & 11 & 3.7 \\
\hline & Muslim & 5 & 1.7 \\
\hline \multirow[t]{4}{*}{ Community } & $\begin{array}{l}\text { Scheduled Castes/ Scheduled } \\
\text { Tribes }\end{array}$ & 111 & 37.0 \\
\hline & Backward Class & 87 & 29.0 \\
\hline & Most Backward Class & 82 & 27.3 \\
\hline & De-notified Communities & 20 & 6.7 \\
\hline \multirow[t]{2}{*}{ Education } & $11^{\text {th }} \mathrm{Std}$ & 157 & 52.3 \\
\hline & $12^{\text {th }}$ Std & 143 & 47.7 \\
\hline \multirow[t]{2}{*}{ Educational Group } & Computer Science with Maths & 74 & 24.7 \\
\hline & Biology with Maths & 87 & 29.0 \\
\hline
\end{tabular}




\begin{tabular}{|c|c|c|c|}
\hline & Pure Science & 72 & 24.0 \\
\hline & $\begin{array}{l}\text { Commerce with Office } \\
\text { Management }\end{array}$ & 67 & 22.3 \\
\hline \multirow[t]{2}{*}{ Family type } & Joint Family & 66 & 22.0 \\
\hline & Nuclear Family & 234 & 78.0 \\
\hline \multirow[t]{3}{*}{ Domicile } & Urban & 18 & 6.0 \\
\hline & Rural & 271 & 90.3 \\
\hline & Tribal & 11 & 3.7 \\
\hline \multirow[t]{6}{*}{ Father's Educational Qualification } & Illiterate & 41 & 13.7 \\
\hline & Elementary & 78 & 26.0 \\
\hline & Middle & 59 & 19.7 \\
\hline & High School & 70 & 23.3 \\
\hline & Higher Secondary & 36 & 12.0 \\
\hline & College Education & 16 & 5.3 \\
\hline \multirow[t]{6}{*}{ Mother's Educational Qualification } & Illiterate & 50 & 16.7 \\
\hline & Elementary & 84 & 28.0 \\
\hline & Middle & 62 & 20.7 \\
\hline & High School & 62 & 20.7 \\
\hline & Higher Secondary & 35 & 11.7 \\
\hline & College Education & 7 & 2.3 \\
\hline \multirow[t]{5}{*}{ Father's Occupation } & Farmer & 103 & 35.6 \\
\hline & Coolie & 173 & 59.7 \\
\hline & Government & 4 & 1.4 \\
\hline & Private & 6 & 2.0 \\
\hline & Self Employed & 4 & 1.3 \\
\hline \multirow[t]{2}{*}{ Mother's Occupational status } & Working & 230 & 77.9 \\
\hline & Not working & 65 & 22.1 \\
\hline \multirow[t]{4}{*}{ Mother's Occupation } & Farmer & 67 & 29.1 \\
\hline & Coolie & 158 & 68.7 \\
\hline & Government & 3 & 1.3 \\
\hline & Private & 2 & 0.9 \\
\hline \multirow[t]{4}{*}{ Family Monthly Income } & Below Rs. 5,000 & 174 & 58.0 \\
\hline & Rs. 5,000-10,000 & 88 & 29.3 \\
\hline & Rs. $10,000-15,000$ & 14 & 4.7 \\
\hline & Above Rs. 15,000 & 24 & 8.0 \\
\hline \multirow[t]{4}{*}{ Ordinal Position } & Single Child & 20 & 6.7 \\
\hline & First Child & 93 & 31.0 \\
\hline & Middle Child & 169 & 56.3 \\
\hline & Last Child & 18 & 6.0 \\
\hline
\end{tabular}

Findings based on the level of self-esteem of adolescents in school:-

The study revealed that more than half (51.3 percentage) of the respondents have low overall level of self-esteem. The following were the hypotheses findings with regard to the level of self-esteem of adolescents. 


\section{Hypotheses Findings}

- There is a significant difference among the age of the respondents with regard to their overall level of selfesteem $(\mathrm{F}=7.171, \mathrm{P}<0.01)$.

- There is significant difference between the gender of the respondents and their overall level of self-esteem $(\mathrm{Z}=$ 4.365, $\mathrm{P}<0.01)$.

- There is no significant relationship between the community of the respondents and their overall level of selfesteem

- There is significant difference between the education of the respondents and their overall level of self-esteem $(\mathrm{Z}=2.598, \mathrm{P}<0.05)$.

- There is a significant association between the educational groups of the respondents with regard to their overall level of self-esteem $\left(\mathrm{x}^{2}=31.469, \mathrm{P}<0.01\right)$.

- There is significant difference between the family type of the respondents and their overall level of self-esteem $(\mathrm{Z}=2.309, \mathrm{P}<0.05)$.

- There is no significant association between the domicile of the respondents and their overall level of selfesteem.

- There is no significant difference among the educational qualification of the respondents fathers' with regard to overall level of self-esteem.

- There is no significant difference between the occupational status of the respondents' mothers with regard to their overall level of self-esteem..

- There is significant relationship between family monthly income of the respondents and overall level of selfesteem $($ value $=0.555, \mathrm{P}<0.01)$.

\section{Conclusion:-}

Self-esteem is the emotional response that people experience as they evaluate different things about themselves. It is an attitude related to personal beliefs about skills, abilities, social relationships, and future outcomes about the self. A positive view of the self allows a person to face life's challenges. The present research study found out that more than half of the adolescents studying in higher secondary school have low overall level of self- esteem and hence they need to improve it. The schools along with focusing on the academic aspect should take care to attend the emotional needs of the adolescents. Especially School Social Workers should be appointed to address such needs of the adolescents rather than the teachers in schools. Application of the direct methods of social work and future research on methods for promoting self-esteem may help reduce the negative feelings of adolescents in schools.

\section{References:-}

1. Akdemir D., Cak T., Aslan C., Aydos B.S., Nalbant K., (2016): Cuhadaroglu-Cetin F. Predictors of selfesteem in adolescents with a psychiatric referral. Turkesh Journal of Pediatrics, 58(1): 69-78.

2. Daniel Clay, Vivian L. Vignoles, Helga Dittmar (2005): Body Image and Self-Esteem Among Adolescent Girls: Testing the influence of Sociocultural Factors. Journal of Research on Adolescence, 15(4): 451-477.

3. Harter, S. (1999): The construction of the self. New York: Guilford.

4. Lauren G. Wild, Alan J. Flisher, Arvin Bhana, Carl Lombard (2004): Associations among adolescent risk behaviours and self-esteem in six domains. The Journal of Child Psychology and Psychiatry, 45(8): 14541467.

5. Monique Bolognini, Bernard Plancherel, Walter Bettschart, Olivier Halfon (1996): Self- esteem and mental health in early adolescence: development and gender differences.

6. Journal of Adolescence, 19(3): 233-245.

7. O’Donnell, W.J. (1976): Adolescent self-esteem related to feelings toward parents and friends. Journal of youth and Adolescence. 5: 179-186. 